\title{
Modeling the Growth of Sudangrass Cultivars at Sowing Times
}

\author{
Rafael Vieira Pezzini ${ }^{1}$, Alberto Cargnelutti Filho ${ }^{2}$, Fernanda Carini ${ }^{1}$, Cirineu Tolfo Bandeira ${ }^{1}$, \\ Jéssica Andiara Kleinpaul ${ }^{1} \&$ Daniela Lixinski Silveira ${ }^{1}$ \\ ${ }^{1}$ Postgraduate Program in Agronomy, Federal University of Santa Maria, Santa Maria, Brazil \\ ${ }^{2}$ Department of Crop Science, Federal University of Santa Maria, Santa Maria, Rio Grande do Sul, Brazil \\ Correspondence: Alberto Cargnelutti Filho, Department of Crop Science, Federal University of Santa Maria, \\ Avenida Roraima, ${ }^{\circ}$ 1000, Bairro Camobi, CEP 97105-900, Santa Maria, RS, Brazil. Tel: 55-553-220-8899. \\ E-mail: alberto.cargnelutti.filho@gmail.com
}

Received: April 15, 2019

doi:10.5539/jas.v11n14p83
Accepted: June 12, 2019 Online Published: August 31, 2019

URL: https://doi.org/10.5539/jas.v11n14p83

\begin{abstract}
This study aimed to fit the Gompertz and Logistic growth models to evaluate the description of fresh and dry masses of shoot as a function of accumulated thermal sum and accumulated solar radiation, to compare the fittings, and to indicate which one best describes the growth of two sudangrass cultivars at four sowing times. Eight uniformity trials were conducted with the sudangrass crop. Five plants were collected from each trial for weighing of fresh and dry shoot masses. These evaluations were carried out three times a week starting from 15 days after plant emergence. The Gompertz and Logistic models were fitted to the masses as a function of accumulated thermal sum and accumulated solar radiation. The parameters and their confidence intervals were estimated. The points of maximum acceleration, inflection, maximum deceleration and asymptotic deceleration, and fit quality indicators were calculated. The intrinsic nonlinearity and the parameter-effects nonlinearity were quantified. The independent variables accumulated thermal sum and accumulated solar radiation can be used to fit the models. Both models satisfactorily describe the growth of fresh and dry shoot masses of cultivars BRS Estribo and CG Farrapo. The Logistic model is more accurate.
\end{abstract}

Keywords: Sorghum sudanense (Piper) Stapf., nonlinear models, yield traits, cover crops

\section{Introduction}

In the no-till system, cover crops are used in rotation with cash crops to control losses of soil, water, and nutrients by water erosion (Cardoso, Silva, Carvalho, Freitas, \& Avanzi, 2012), to promote nutrient cycling, and to increase soil organic matter contents (Pacheco et al., 2013).

Sudangrass [Sorghum sudanense (Piper) Stapf.] is among the many species that have been investigated as alternative cover crop options. Sudangrass belongs to the family Poaceae, develops well in regions with hot and dry climate, and tolerates acid and low fertility soils. It yields high amounts of biomass, reaching 84.3 tha $^{-1}$ of fresh mass and 15.8 tha $^{-1}$ of dry mass (Arenhardt et al., 2016) and providing good soil cover and high weed suppressive effect (Borges, Freitas, Mateus, Sá, \& Alves, 2014). It has good nutritional quality and can be used in animal feed (Mattos, 2003). Reports on the growth and development of this species are scarce, indicating the need for studies to obtain more information on this process.

The fitting of growth models provides a valuable tool to study plant behavior and the occurrence of phenological stages (Lucena, Leite, Pereira, \& Cavalcante, 2016). It is possible to plan periods and types of management more appropriate for the crop using these models, aiming to reach higher yields (Pereira, Morais, Scalco, \& Fernandes, 2014). In addition, the fit of models in function of meteorological variables makes it possible to understand the growth according to the environmental characteristics (Oliveira, Ribeiro, Silva, Xavier, \& Freitas, 2017).

Different statistical models can be used to study plant growth. The nonlinear models provide the best fits and have an advantage over linear models because they have biologically interpretable parameters (Fernandes, Pereira, Muniz, \& Savian, 2014).

The nonlinear Gompertz and Logistic models are used to describe plant growth, as they have the same sigmoidal shape of the growth curves. These two models were studied to describe the growth of sunflower (Bem et al., 
2018), cocoa (Muniz, Nascimento, \& Fernandes, 2017), and coffee cultivar Rubi MG 1192 (Pereira et al., 2014) and were considered adequate.

The objectives of this work were to fit the Gompertz and Logistic growth models to evaluate the description of fresh and dry shoot masses as a function of accumulated thermal sum and accumulated solar radiation, to compare the fittings, and to indicate which one best describes the growth of two sudangrass cultivars at four sowing times.

\section{Material and Methods}

Eight uniformity trials were conducted with sudangrass [Sorghum sudanense (Piper) Stapf.] in the experimental area located between coordinates $29^{\circ} 42^{\prime} \mathrm{S}, 53^{\circ} 49^{\prime} \mathrm{W}$ and $95 \mathrm{~m}$ altitude. According to Köppen's classification, the climate of the region is humid subtropical Cfa, with hot summers and no defined dry season (Alvares, Stape, Sentelhas, Gonçalves, \& Sparovek, 2013). The soil is classified as Sandy Dystrophic Red Argisol (Santos et al. 2013).

The uniformity trials consisted of two cultivars (BRS Estribo and CG Farrapo) sown at four dates (12/20/2016, 01/20/2017, 02/07/2017, and 02/24/2017), during the period recommended for the crop in the state of Rio Grande do Sul, between October and February (Silveira, Santanna, Montardo, \& Trentin, 2015). In each experiment, sowing was performed in rows spaced $0.4 \mathrm{~m}$ apart, with density of $25 \mathrm{kgha}^{-1}$ of viable seeds, in an area of $9 \mathrm{~m} \times 16 \mathrm{~m}\left(144 \mathrm{~m}^{2}\right)$. The basal fertilization consisted of $33 \mathrm{kgha}^{-1}$ of $\mathrm{N}, 132 \mathrm{kgha}^{-1}$ of $_{2} \mathrm{P}_{2} \mathrm{O}_{5}$, and 132 $\mathrm{kgha}^{-1}$ of $\mathrm{K}_{2} \mathrm{O}$. When the plants had three to four leaves, $67.5 \mathrm{kgha}^{-1}$ of $\mathrm{N}\left(150 \mathrm{kgha}^{-1}\right.$ of urea) was applied as topdress.

Plants were evaluated three times a week, the first evaluation started from 15 days after plant emergence. At each evaluation, five plants were collected from each experiment and fresh shoot mass (FSM, g plant ${ }^{-1}$ ) was weighed with a digital scale. For dry shoot mass $\left(\mathrm{DSM}, \mathrm{g} \mathrm{plant}^{-1}\right)$, the fresh material was packed in paper bags and dried in an oven at $60{ }^{\circ} \mathrm{C}$ to constant mass. In total, 17, 18, 26 and 21 evaluations were performed in BRS Estribo and 19, 20, 22 and 20 evaluations in CG Farrapo for the FSM trait at times 1, 2, 3 and 4, respectively. For the DSM trait were performed 20, 24, 27 and 21 evaluations in BRS Estribo and 22, 24, 26 and 23 evaluations in CG Farrapo at times 1,2,3 and 4, respectively.

Maximum and minimum air temperatures, as degree Celsius, and the incident global solar radiation, as $\mathrm{MJm}^{-2}$, from the first sowing date (December 20, 2016) to the last evaluation of the fourth sowing date (May 29, 2017) were obtained from the records of the INMET Automatic Meteorological Station, which is located at $30 \mathrm{~m}$ from the experimental area.

With the temperature data, the daily thermal sum was calculated by the method proposed by Arnold (1960), according to Equation 1:

$$
\mathrm{STd}=\frac{\mathrm{Tmax}+\mathrm{Tmin}}{2}-\mathrm{Tb}
$$

where, STd is the daily thermal sum, Tmax is the maximum temperature of the day, Tmin is the minimum temperature of the day, and $\mathrm{Tb}$ is the minimum base temperature of grain sorghum BRS 511 , which is $10.8{ }^{\circ} \mathrm{C}$ (Bandeira et al., 2016). Because no base temperature studies were found for sudangrass, we used the base temperature of the grain sorghum, as they belong to the same genus. Then, the accumulated thermal sum (ATS) was calculated by summing the STd values from the period between the emergence of the plants and the last evaluation of each cultivar in each date. We use the same procedure to calculate the accumulated solar radiation (ASR), i.e., summing the daily values of the incident global solar radiation of the same period.

The Gompertz and Logistic models were adjusted to fit fresh and dry shoot masses obtained from the five plants collected for each evaluation, according to ATS and ASR. For the Gompertz model, we used Equation 2 and for the Logistic model, we used Equation 3:

$$
\begin{aligned}
& y_{i}=a \cdot \exp [-\exp (b-c x)]+\varepsilon_{i} \\
& y_{i}=a /[1+\exp (-b-c x)]+\varepsilon_{i}
\end{aligned}
$$

where, $y_{i}$ represents the $\mathrm{i}$-th observation of the dependent variable and $\mathrm{i}=1,2, \ldots, \mathrm{n} ; a$ is the asymptotic value or final growth value; $b$ is the curve allocation parameter, which has no biological interpretation, but is fundamental to the sigmoidal shape of the curve; $c$ is the maximum relative growth rate or precocity index; $x$ is the independent variable; and $\varepsilon_{i}$ is the random error associated with the $\mathrm{i}$-th observation which is assumed to have a normal distribution, independent form and constant variances. The parameters were estimated using the ordinary least squares method, using the Gauss-Newton iterative process. 
The assumptions of normality, homoscedasticity, and independence of errors were tested by the Shapiro-Wilk, Bartlett, and Durbin-Watson tests, respectively.

In each model, the points of maximum acceleration (PMA), inflection (PI), maximum deceleration (PMD), and asymptotic deceleration (PAD) were calculated using the equations described by Mischan and Pinho (2014). These critical points can be used to infer about the growth of the crop.

The lower and upper limits of the $95 \%$ confidence interval were calculated. Plant growth models were compared between cultivars at each sowing date and between sowing dates in each cultivar by the overlapping of confidence intervals of the parameters. For example, to compare dates, if at least one of the estimates of a trait for a given date is contained in the confidence interval of the parameter of the same trait of another date, the dates are not different. If none of the estimates is contained within the interval of the other, then they are different.

To evaluate the quality of fit of the models, the following indicators were calculated: adjusted coefficient of determination $\left(\mathrm{R}^{2} \mathrm{aj}\right)$; the Akaike information criterion (AIC); and residual standard deviation (RSD). The intrinsic nonlinearity (IN) and the parameter-effects nonlinearity (PE) were quantified. The best models are those with the highest $\mathrm{R}^{2}$ aj and the lowest AIC, RSD, IN and PE. Calculations were performed using the software R (R Development Core Team, 2018) and the Microsoft Office Excel® application.

\section{Results and Discussion}

In choosing a growth model, one of the factors that must be taken into consideration is how the data disperses. Plant growth studies usually present data in the sigmoid shape, which are characteristic of nonlinear models, such as Gompertz and Logistic. In Figure 1, for example, were plotted the data from the trials with the sudangrass cultivars. It is possible to observe that the fresh shoot mass (FSM) and the dry shoot mass (DSM) as a function of accumulated solar radiation (ASR), showed dispersion in the sigmoidal shape, justifying the fit of the Gompertz and Logistic models. 

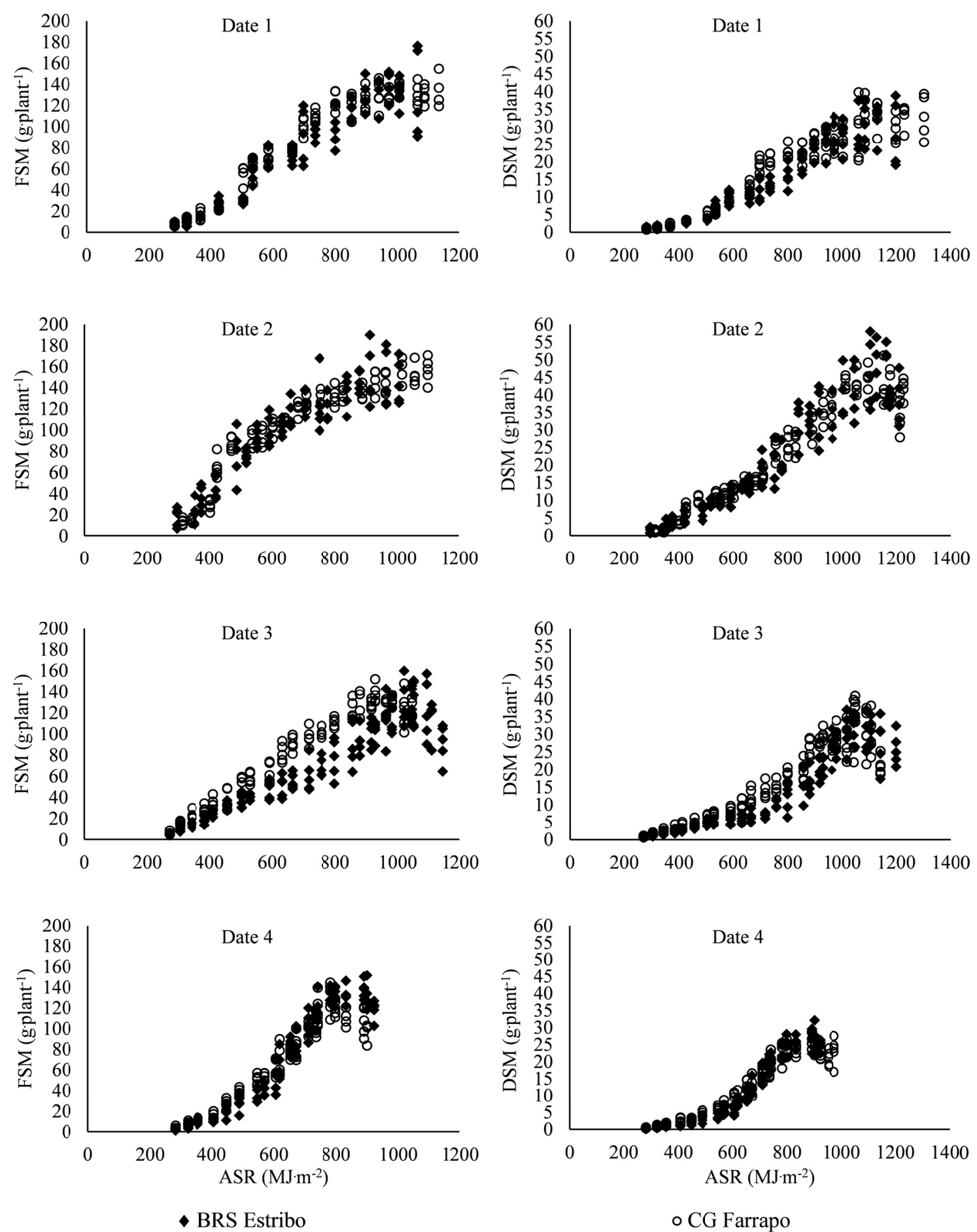

Figure 1. Scatterplot of dataset of the traits as a function of accumulated solar radiation (ASR), of sudangrass cultivars BRS Estribo and CG Farrapo sown at four dates

After to fit the models, the residuals analyses carried out to evaluate assumptions of normality, homoscedasticity, and independence of the errors of the models fitted for fresh and dry shoot masses as a function of ATS and ASR showed that all assumptions were met, with $\mathrm{p}$-values greater than $0.05(\mathrm{p}>0.05)$ obtained from the Shapiro-Wilk, Bartlett, and Durbin-Watson tests, respectively. These results agree with those reported by Ribeiro, Mattos, Morais and Muniz (2018) in the study of pequi (Caryocar brasiliense) growth.

The estimates of the parameters $a, b$, and $c$ are used to predict the growth of the plant and to compare the growth of the cultivars within each sowing date and between the sowing dates of the same cultivar. One way to do the 
comparison is by the overlapping of confidence intervals of the parameters, a method used by Bem et al. (2018) to compare sowing dates of crotalária juncea.

The Gompertz and Logistic models of FSM as a function of ATS showed that the cultivars BRS Estribo and CG Farrapo were not different at date 2 , that is, they had similar values for the parameters $a, b$, and $c$ (Table 1 ). In this condition, it is assumed that the cultivars had the same growth behavior. At dates 1 and 3 , the cultivars showed similar asymptotic values (parameter $a$ ), that is, they did not differ for the trait at the end of the crop cycle. For DSM, the models showed that the cultivars had the same growth behavior at dates 1, 2 and 3. At date 4, the cultivars differed in the asymptotic value, and BRS Estribo had asymptote higher than CG Farrapo, both for FSM and DSM. However, the cultivars did not differ in the precocity index.

Table 1. Estimates of parameters and lower limit (LL) and upper limit (UL) of the 95\% confidence interval of the Gompertz and Logistic models, for the traits as a function of the accumulated thermal sum, of sudangrass cultivars BRS Estribo and CG Farrapo sown at four dates

\begin{tabular}{|c|c|c|c|c|c|c|c|c|c|c|c|c|c|}
\hline \multirow{3}{*}{ Trait $^{(1)}$} & \multirow{3}{*}{ Parameter ${ }^{(2)}$} & Estimate & LL & UL & Estimate & LL & UL & Estimate & LL & UL & Estimate & LL & UL \\
\hline & & \multicolumn{6}{|c|}{ 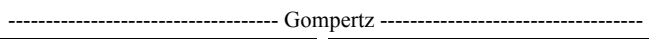 } & \multicolumn{6}{|c|}{-- } \\
\hline & & \multicolumn{3}{|c|}{ BRS Estribo } & \multicolumn{3}{|c|}{ CG Farrapo } & \multicolumn{3}{|c|}{ BRS Estribo } & \multicolumn{3}{|c|}{ CG Farrapo } \\
\hline \multicolumn{14}{|c|}{ Date $1(12 / 20 / 2016)$} \\
\hline & $\mathrm{a}(\mathrm{ns})(\mathrm{ns})$ & 147.7166 & 133.1482 & 162.2851 & 136.7571 & 132.5847 & 140.9295 & 138.6315 & 128.8570 & 148.4059 & 133.1332 & 129.8595 & 136.4070 \\
\hline \multirow[t]{3}{*}{ FSM } & $\mathrm{b}(\mathrm{ns})(\mathrm{ns})$ & 3.1465 & 2.4628 & 3.8303 & 3.8216 & 3.3773 & 4.2659 & -5.5960 & -6.6111 & -4.5810 & -6.3638 & -7.0162 & -5.7114 \\
\hline & $\mathrm{c}(*)(*)$ & 0.0075 & 0.0057 & 0.0093 & 0.0097 & 0.0086 & 0.0109 & 0.0121 & 0.0096 & 0.0145 & 0.0147 & 0.0131 & 0.0163 \\
\hline & $\mathrm{a}(\mathrm{ns})(\mathrm{ns})$ & 34.8720 & 30.6655 & 39.0784 & 33.1462 & 31.2391 & 35.0533 & 31.7754 & 29.4122 & 34.1386 & 31.6443 & 30.1955 & 33.0931 \\
\hline \multirow[t]{2}{*}{ DSM } & $\mathrm{b}(\mathrm{ns})(\mathrm{ns})$ & 3.0350 & 2.3776 & 3.6924 & 3.3030 & 2.7309 & 3.8750 & -5.8497 & -6.8501 & -4.8492 & -5.7634 & -6.6634 & -4.8633 \\
\hline & c (ns) (ns) & 0.0060 & 0.0045 & 0.0075 & 0.0072 & 0.0059 & 0.0085 & 0.0105 & 0.0085 & 0.0126 & 0.0113 & 0.0094 & 0.0132 \\
\hline \multicolumn{14}{|c|}{ Date $2(01 / 20 / 2017)$} \\
\hline & a (ns) (ns) & 165.3004 & 146.4820 & 184.1188 & 156.6290 & 150.0656 & 163.1924 & 153.7560 & 141.3565 & 166.1555 & 150.9557 & 145.4085 & 156.5030 \\
\hline \multirow[t]{3}{*}{ FSM } & $\mathrm{b}(\mathrm{ns})(\mathrm{ns})$ & 2.1239 & 1.6604 & 2.5874 & 2.3898 & 2.0827 & 2.6969 & -3.8300 & -4.5207 & -3.1393 & -3.9795 & -4.4732 & -3.4858 \\
\hline & $\mathrm{c}(\mathrm{ns})(\mathrm{ns})$ & 0.0058 & 0.0043 & 0.0074 & 0.0068 & 0.0059 & 0.0077 & 0.0092 & 0.0072 & 0.0112 & 0.0098 & 0.0085 & 0.0112 \\
\hline & $\mathrm{a}(\mathrm{ns})(\mathrm{ns})$ & 52.8258 & 45.0829 & 60.5686 & 53.3124 & 46.4294 & 60.1953 & 46.3964 & 42.8319 & 49.9609 & 45.7447 & 42.8408 & 48.6486 \\
\hline \multirow[t]{2}{*}{ DSM } & $\mathrm{b}(\mathrm{ns})(\mathrm{ns})$ & 2.8482 & 2.1985 & 3.4979 & 2.3876 & 1.9918 & 2.7834 & -5.8537 & -6.8618 & -4.8456 & -5.0966 & -5.7338 & -4.4593 \\
\hline & $\mathrm{c}(\mathrm{ns})(\mathrm{ns})$ & 0.0052 & 0.0037 & 0.0066 & 0.0043 & 0.0034 & 0.0053 & 0.0098 & 0.0079 & 0.0117 & 0.0085 & 0.0073 & 0.0097 \\
\hline \multicolumn{14}{|c|}{ Date $3(02 / 07 / 2017)$} \\
\hline & a (ns) (ns) & 145.3179 & 124.3713 & 166.2646 & 142.3280 & 135.0317 & 149.6242 & 129.1003 & 118.3388 & 139.8618 & 133.4360 & 129.1684 & 137.7036 \\
\hline \multirow[t]{3}{*}{ FSM } & $\mathrm{b}(*)(\mathrm{ns})$ & 2.3823 & 1.8900 & 2.8746 & 2.9402 & 2.5677 & 3.3126 & -4.6729 & -5.4191 & -3.9266 & -5.3787 & -5.9044 & -4.8529 \\
\hline & $\mathrm{c}\left({ }^{*}\right)(*)$ & 0.0047 & 0.0035 & 0.0060 & 0.0070 & 0.0060 & 0.0079 & 0.0084 & 0.0068 & 0.0101 & 0.0115 & 0.0102 & 0.0127 \\
\hline & $\mathrm{a}(\mathrm{ns})(\mathrm{ns})$ & 42.8488 & 33.5872 & 52.1105 & 34.5175 & 30.5277 & 38.5072 & 34.2185 & 31.0511 & 37.3858 & 31.4017 & 29.3163 & 33.4871 \\
\hline \multirow[t]{2}{*}{ DSM } & b (ns) (ns) & 3.0877 & 2.4123 & 3.7630 & 3.1608 & 2.4842 & 3.8375 & -6.8787 & -7.9525 & -5.8048 & -6.0836 & -7.0767 & -5.0904 \\
\hline & $\mathrm{c}(\mathrm{ns})(\mathrm{ns})$ & 0.0048 & 0.0034 & 0.0062 & 0.0060 & 0.0045 & 0.0076 & 0.0104 & 0.0085 & 0.0123 & 0.0107 & 0.0087 & 0.0126 \\
\hline \multicolumn{14}{|c|}{ Date $4(02 / 24 / 2017)$} \\
\hline & $\mathrm{a}(*)(*)$ & 166.5907 & 147.4389 & 185.7425 & 142.2458 & 123.4944 & 160.9972 & 143.7331 & 135.6813 & 151.7849 & 125.9214 & 116.3544 & 135.4885 \\
\hline \multirow[t]{3}{*}{ FSM } & $\mathrm{b}(\mathrm{ns})(*)$ & 3.1988 & 2.6717 & 3.7260 & 2.6310 & 2.1364 & 3.1257 & -6.5338 & -7.2993 & -5.7684 & -5.1675 & -5.9187 & -4.4163 \\
\hline & c (ns) (ns) & 0.0075 & 0.0060 & 0.0091 & 0.0069 & 0.0053 & 0.0086 & 0.0145 & 0.0126 & 0.0164 & 0.0125 & 0.0103 & 0.0146 \\
\hline & $\mathrm{a}(*)(*)$ & 38.5865 & 31.5646 & 45.6085 & 28.9069 & 25.5407 & 32.2731 & 30.0266 & 27.8012 & 32.2520 & 25.5919 & 24.0349 & 27.1490 \\
\hline \multirow[t]{2}{*}{ DSM } & b (ns) $(*)$ & 3.6499 & 2.9794 & 4.3205 & 3.1986 & 2.5916 & 3.8056 & -8.0167 & -8.9683 & -7.0651 & -6.4429 & -7.3349 & -5.5509 \\
\hline & c (ns) (ns) & 0.0074 & 0.0056 & 0.0091 & 0.0074 & 0.0058 & 0.0091 & 0.0159 & 0.0137 & 0.0181 & 0.0139 & 0.0117 & 0.0160 \\
\hline
\end{tabular}

Note. ${ }^{(1)}$ FSM: fresh shoot mass, g plant ${ }^{-1}$; DSM: dry shoot mass, g plant ${ }^{-1}$. ${ }^{(2)}$ First column of parentheses represents the comparison of the parameters of the Gompertz model among the cultivars and the second column of parentheses represents the comparison of the parameters of the Logistic model among the cultivars. (*) significant at $5 \%$ probability of error. (ns) not significant.

Comparing the models of FSM as a function of ASR between the cultivars, we found that BRS Estribo and CG Farrapo did not differ in growth behavior at date 2 (Table 2). In addition, no difference was found for parameters $a$ and $b$ at the dates 1 and 3, indicating that the final value of growth of the cultivars was similar in these two dates. There was no difference between the cultivars for DSM at dates 1, 2, and 3 of the Gompertz model and dates 1 and 2 of the Logistic model. In the Logistic model, at date 3, the cultivars differed only in parameter $b$, thus having the same asymptotic value and the same precocity index. At date 4 , there were differences between 
the cultivars, except for parameter $c$ in the Gompertz model of DSM. At that date, the cultivars showed different final values of growth for FSM and DSM, and BRS Estribo was superior to CG Farrapo.

Table 2. Estimates of parameters and lower limit (LL) and upper limit (UL) of the $95 \%$ confidence interval of the Gompertz and Logistic models, for the traits as a function of the accumulated solar radiation, of sudangrass cultivars BRS Estribo and CG Farrapo sown at four dates

\begin{tabular}{|c|c|c|c|c|c|c|c|c|c|c|c|c|c|}
\hline \multirow{3}{*}{ Trait $^{(1)}$} & \multirow{3}{*}{ Parameter $^{(2)}$} & Estimate & LL & UL & Estimate & LL & UL & Estimate & LL & UL & Estimate & LL & UL \\
\hline & & \multicolumn{6}{|c|}{ - } & \multicolumn{6}{|c|}{ - Logistic - - } \\
\hline & & \multicolumn{3}{|c|}{ BRS Estribo } & \multicolumn{3}{|c|}{ CG Farrapo } & \multicolumn{3}{|c|}{ BRS Estribo } & \multicolumn{3}{|c|}{ CG Farrapo } \\
\hline \multicolumn{14}{|c|}{ Date $1(12 / 20 / 2016)$} \\
\hline & $\mathrm{a}(\mathrm{ns})(\mathrm{ns})$ & 157.5072 & 136.3393 & 178.6751 & 139.9595 & 134.5924 & 145.3266 & 142.3092 & 130.2936 & 154.3249 & 134.2892 & 130.5627 & 138.0157 \\
\hline \multirow[t]{3}{*}{ FSM } & $\mathrm{b}(\mathrm{ns})(\mathrm{ns})$ & 2.4092 & 1.8805 & 2.9378 & 2.9128 & 2.5480 & 3.2776 & -4.6283 & -5.4645 & -3.7922 & -5.1706 & -5.7201 & -4.6210 \\
\hline & $\mathrm{c}(*)(*)$ & 0.0042 & 0.0031 & 0.0054 & 0.0057 & 0.0050 & 0.0064 & 0.0073 & 0.0058 & 0.0089 & 0.0090 & 0.0080 & 0.0100 \\
\hline & $\mathrm{a}(\mathrm{ns})(\mathrm{ns})$ & 38.9466 & 31.5645 & 46.3288 & 34.6232 & 31.9265 & 37.3198 & 33.3124 & 29.9354 & 36.6894 & 32.3684 & 30.5826 & 34.1543 \\
\hline \multirow[t]{2}{*}{ DSM } & $\mathrm{b}(\mathrm{ns})(\mathrm{ns})$ & 2.5292 & 1.9545 & 3.1039 & 2.7593 & 2.2453 & 3.2733 & -5.2108 & -6.1090 & -4.3127 & -5.0097 & -5.8031 & -4.2162 \\
\hline & $\mathrm{c}(\mathrm{ns})(\mathrm{ns})$ & 0.0035 & 0.0024 & 0.0046 & 0.0044 & 0.0035 & 0.0053 & 0.0067 & 0.0053 & 0.0081 & 0.0071 & 0.0059 & 0.0084 \\
\hline \multicolumn{14}{|c|}{ Date $2(01 / 20 / 2017)$} \\
\hline & a (ns) (ns) & 155.6587 & 143.6141 & 167.7032 & 152.7294 & 147.4974 & 157.9614 & 148.0270 & 139.3323 & 156.7217 & 148.7353 & 144.0440 & 153.4266 \\
\hline \multirow[t]{3}{*}{ FSM } & $\mathrm{b}(\mathrm{ns})(\mathrm{ns})$ & 2.4630 & 1.9590 & 2.9670 & 2.7045 & 2.3687 & 3.0404 & -4.2882 & -5.0599 & -3.5165 & -4.3881 & -4.9287 & -3.8474 \\
\hline & $\mathrm{c}(\mathrm{ns})(\mathrm{ns})$ & 0.0055 & 0.0043 & 0.0067 & 0.0061 & 0.0054 & 0.0069 & 0.0084 & 0.0067 & 0.0100 & 0.0087 & 0.0076 & 0.0099 \\
\hline & $\mathrm{a}(\mathrm{ns})(\mathrm{ns})$ & 53.1173 & 45.5248 & 60.7098 & 49.7498 & 45.0390 & 54.4607 & 46.4395 & 42.9037 & 49.9752 & 44.4370 & 42.1348 & 46.7391 \\
\hline \multirow[t]{2}{*}{ DSM } & $\mathrm{b}(\mathrm{ns})(\mathrm{ns})$ & 2.5375 & 2.0266 & 3.0484 & 2.4125 & 2.0513 & 2.7738 & -5.1667 & -5.9643 & -4.3692 & -4.8706 & -5.4275 & -4.3137 \\
\hline & $\mathrm{c}(\mathrm{ns})(\mathrm{ns})$ & 0.0036 & 0.0027 & 0.0045 & 0.0036 & 0.0029 & 0.0043 & 0.0068 & 0.0055 & 0.0080 & 0.0066 & 0.0057 & 0.0075 \\
\hline \multicolumn{14}{|c|}{ Date $3(02 / 07 / 2017)$} \\
\hline & $\mathrm{a}(\mathrm{ns})(\mathrm{ns})$ & 157.0524 & 126.3304 & 187.7744 & 147.4673 & 138.1783 & 156.7564 & 133.8488 & 119.5894 & 148.1081 & 135.7613 & 130.5336 & 140.9890 \\
\hline \multirow[t]{3}{*}{ FSM } & $\mathrm{b}(\mathrm{ns})(\mathrm{ns})$ & 1.9345 & 1.5596 & 2.3093 & 2.2105 & 1.9474 & 2.4737 & -4.0088 & -4.6270 & -3.3906 & -4.2287 & -4.6307 & -3.8267 \\
\hline & $\mathrm{c}(*)(*)$ & 0.0030 & 0.0021 & 0.0039 & 0.0043 & 0.0037 & 0.0050 & 0.0057 & 0.0045 & 0.0068 & 0.0073 & 0.0065 & 0.0081 \\
\hline & $\mathrm{a}(\mathrm{ns})(\mathrm{ns})$ & 40.3016 & 32.3756 & 48.2277 & 36.8112 & 30.9823 & 42.6401 & 33.9301 & 30.7953 & 37.0649 & 32.1363 & 29.4733 & 34.7992 \\
\hline \multirow[t]{2}{*}{ DSM } & $\mathrm{b}(\mathrm{ns})(*)$ & 3.2675 & 2.4667 & 4.0682 & 2.5572 & 1.9972 & 3.1172 & -6.9857 & -8.1814 & -5.7901 & -5.2988 & -6.1901 & -4.4074 \\
\hline & $\mathrm{c}(\mathrm{ns})(\mathrm{ns})$ & 0.0041 & 0.0028 & 0.0053 & 0.0038 & 0.0028 & 0.0049 & 0.0083 & 0.0067 & 0.0099 & 0.0073 & 0.0059 & 0.0087 \\
\hline \multicolumn{14}{|c|}{ Date $4(02 / 24 / 2017)$} \\
\hline & $\mathrm{a}(*)(*)$ & 147.7594 & 137.2317 & 158.2871 & 132.6186 & 119.4853 & 145.7519 & 138.0029 & 132.2227 & 143.7831 & 122.1188 & 114.7901 & 129.4474 \\
\hline \multirow[t]{3}{*}{ FSM } & $\mathrm{b}\left({ }^{*}\right)(*)$ & 4.6265 & 3.8146 & 5.4385 & 3.3604 & 2.6941 & 4.0266 & -8.2732 & -9.2920 & -7.2543 & -6.3542 & -7.3179 & -5.3904 \\
\hline & $\mathrm{c}(*)(*)$ & 0.0079 & 0.0065 & 0.0094 & 0.0063 & 0.0049 & 0.0077 & 0.0132 & 0.0115 & 0.0150 & 0.0110 & 0.0091 & 0.0128 \\
\hline & $\mathrm{a}\left({ }^{*}\right)(*)$ & 30.0615 & 27.7609 & 32.3622 & 26.2948 & 24.3496 & 28.2400 & 27.7710 & 26.5328 & 29.0091 & 24.7095 & 23.6013 & 25.8176 \\
\hline \multirow[t]{2}{*}{ DSM } & $\mathrm{b}\left({ }^{*}\right)(*)$ & 5.6082 & 4.7013 & 6.5151 & 4.4128 & 3.5662 & 5.2595 & -9.9048 & -11.0077 & -8.8018 & -7.8805 & -8.9704 & -6.7907 \\
\hline & $\mathrm{c}(\mathrm{ns})\left({ }^{*}\right)$ & 0.0087 & 0.0072 & 0.0102 & 0.0074 & 0.0059 & 0.0089 & 0.0145 & 0.0128 & 0.0163 & 0.0123 & 0.0105 & 0.0141 \\
\hline
\end{tabular}

Note. ${ }^{(1)}$ FSM: fresh shoot mass, g plant ${ }^{-1}$; DSM: dry shoot mass, g plant ${ }^{-1} .{ }^{(2)}$ First column of parentheses represents the comparison of the parameters of the Gompertz model among the cultivars and the second column of parentheses represents the comparison of the parameters of the Logistic model among the cultivars. $(*)$ significant at $5 \%$ probability of error. (ns) not significant.

The comparisons showed that the cultivars BRS Estribo and CG Farrapo had distinct growth behaviors within the sowing dates. These differences were more evident for fresh shoot mass. Differences in growth between cultivars were observed in studies of dry mass accumulation during sugarcane formation (Batista et al., 2013).

Besides the comparisons between the cultivars, comparisons were made between the sowing dates within each cultivar. We found that in the models fitted as a function of ATS, the FSM of cv. BRS Estribo showed no difference between dates 1 and 4 and 2 and 3 in the Gompertz model, as well as between dates 1 and 4 of the Logistic model. For the parameter $a$ in the Gompertz model, there were differences only between the asymptotic values of the trait between dates 3 and 4 . In the Logistic model, dates 1 and 3 and 2 and 4 showed no difference in the parameter $a$. For DSM, there were no differences between dates 1 and 3 and 1 and 4 in the Gompertz model, while in the Logistic model, there were no differences between dates 1 and 3 . The parameter $a$ showed similar values in the dates 3 and 4, in the Gompertz model, and 1 and 4, in the Logistic model.

Cultivar CG Farrapo showed similar behavior between dates 2 and 4 and 3 and 4 in the Gompertz model and between 3 and 4 in the Logistic model for FSM. Similar asymptotic values were found between dates 1 and 3 and 1 and 4 of both models. DSM showed no differences between dates 1 and 3 in both models. 
Regarding the models fitted as a function of ASR, there was no similar behavior of cv. BRS Estribo for the trait FSM, between the dates in the Gompertz model, whereas in the Logistic model, similar behavior was observed between dates 1 and 2. For the Gompertz model, all dates showed similar values of $a$, that is, non-different final value of growth. For the trait DSM, the dates 1 and 3 were not different in the Gompertz model, whereas in the Logistic model, these same dates showed similar values of $a$ and $c$, but different for parameter $b$.

In the models of cv. CG Farrapo, similar behavior for FSM was found in dates 1 and 4 of the Gompertz model, as well as in dates 1 and 3 of both models for DSM. Similar behavior for the asymptotic value was found in dates 1 and 3 and 2 and 3, in the Gompertz model, and 1 and 3, in the Logistic model, for FSM.

Therefore, as for the cultivars, there were differences in behavior between the sowing dates of each cultivar. In crotalária juncea, Bem et al. (2018) observed differences between sowing dates for fresh and dry masses of the plants. These results are due to differences in the meteorological conditions and/or biotic factors that affect the crop and result in different responses of the plant in its growth.

In order to indicate the model that best describes the growth of the sudangrass cultivars in the four sowing dates, we calculated the adjusted coefficient of determination $\left(R^{2} a j\right)$, the Akaike information criterion (AIC), the residual standard deviation (RSD) and quantified the parameter-effects nonlinearity (PE) and the intrinsic nonlinearity (IN). For the traits FSM and DSM, both models were appropriate, with $\mathrm{R}^{2}$ aj values equal to or greater than 0.8721 when fitted for ATS (Table 3), and equal to or greater than 0.8646 when as a function of ASR (Table 4). From these values, we can infer that both the independent variables ATS and ASR were adequate to model the growth of the sudangrass cultivars.

Table 3. Fit quality indicators and critical points of the Gompertz and Logistic models for the traits of fresh shoot mass (FSM) and dry shoot mass (DSM) as a function of accumulated thermal sum $\left({ }^{\circ} \mathrm{C}\right)$ for sudangrass cultivars BRS Estribo and CG Farrapo in four sowing times

\begin{tabular}{|c|c|c|c|c|c|c|c|c|c|}
\hline \multirow{3}{*}{ Statistic $^{(1)}$} & & \multicolumn{4}{|c|}{--------------------- Gompertz ---------------------- } & \multicolumn{4}{|c|}{ - } \\
\hline & & \multicolumn{2}{|c|}{ BRS Estribo } & \multicolumn{2}{|c|}{ CG Farrapo } & \multicolumn{2}{|c|}{ BRS Estribo } & \multicolumn{2}{|c|}{ CG Farrapo } \\
\hline & & FSM & DSM & FSM & DSM & FSM & DSM & FSM & DSM \\
\hline \multicolumn{10}{|c|}{ Date $1(12 / 20 / 2016)$} \\
\hline$R^{2} a j$ & & 0.8993 & 0.8928 & 0.9642 & 0.9169 & 0.8976 & 0.8974 & 0.9659 & 0.9110 \\
\hline AIC & & 5.5479 & 2.7021 & 4.4262 & 2.5172 & 5.5635 & 2.6589 & 4.3803 & 2.5841 \\
\hline RSD & & 15.4716 & 3.7498 & 8.8715 & 3.4264 & 15.5952 & 3.6680 & 8.6616 & 3.5455 \\
\hline PE & & 0.9414 & 1.1395 & 0.2708 & 0.4922 & 0.5675 & 0.5529 & 0.1956 & 0.3336 \\
\hline IN & & 0.1418 & 0.1584 & 0.0883 & 0.1330 & 0.1223 & 0.1190 & 0.0737 & 0.1110 \\
\hline \multirow[t]{2}{*}{ PI } & $\mathrm{x}$ & 419.3274 & 507.0559 & 392.1039 & 460.9001 & 463.2785 & 554.5061 & 433.2996 & 509.9653 \\
\hline & $\mathrm{y}$ & 54.3419 & 12.8287 & 50.3101 & 12.1938 & 69.3157 & 15.8877 & 66.5666 & 15.8221 \\
\hline \multirow[t]{2}{*}{ PMA } & $\mathrm{x}$ & 291.0689 & 346.2634 & 293.3569 & 326.6025 & 354.2518 & 429.6683 & 343.6309 & 393.4355 \\
\hline & $\mathrm{y}$ & 10.7754 & 2.5438 & 9.9759 & 2.4179 & 29.2963 & 6.7149 & 28.1344 & 6.6872 \\
\hline \multirow[t]{2}{*}{ PMD } & $\mathrm{x}$ & 547.5859 & 667.8485 & 490.8510 & 595.1977 & 572.3052 & 679.3439 & 522.9684 & 626.4952 \\
\hline & $\mathrm{y}$ & 100.8193 & 23.8008 & 93.3392 & 22.6229 & 109.3352 & 25.0605 & 104.9989 & 24.9571 \\
\hline \multirow[t]{2}{*}{ PAD } & $\mathrm{x}$ & 658.8378 & 807.3205 & 576.5046 & 711.6879 & 653.0615 & 771.8116 & 589.3862 & 712.8091 \\
\hline & $\mathrm{y}$ & 125.1532 & 29.5454 & 115.8677 & 28.0832 & 125.9118 & 28.8600 & 120.9180 & 28.7409 \\
\hline \multicolumn{10}{|c|}{ Date $2(01 / 20 / 2017)$} \\
\hline$R^{2} a j$ & & 0.8792 & 0.8741 & 0.9495 & 0.9148 & 0.8745 & 0.8871 & 0.9371 & 0.9270 \\
\hline AIC & & 5.6060 & 3.5399 & 4.6896 & 2.9804 & 5.6436 & 3.4320 & 4.9089 & 2.8251 \\
\hline RSD & & 15.9574 & 5.7387 & 10.1285 & 4.3320 & 16.2629 & 5.4332 & 11.3116 & 4.0097 \\
\hline $\mathrm{PE}$ & & 1.3576 & 1.5475 & 0.4622 & 1.4263 & 0.8180 & 0.6211 & 0.3693 & 0.5202 \\
\hline IN & & 0.0916 & 0.1766 & 0.0579 & 0.1089 & 0.1051 & 0.1216 & 0.0747 & 0.0830 \\
\hline \multirow[t]{2}{*}{ PI } & $\mathrm{x}$ & 363.2564 & 552.9506 & 350.8924 & 553.5216 & 415.4570 & 596.8194 & 404.3784 & 599.5227 \\
\hline & $\mathrm{y}$ & 60.8106 & 19.4335 & 57.6206 & 19.6125 & 76.8782 & 23.1981 & 75.4779 & 22.8723 \\
\hline \multirow[t]{2}{*}{ PMA } & $\mathrm{x}$ & 198.6521 & 366.1052 & 209.5792 & 330.4009 & 272.6006 & 462.5487 & 270.5541 & 444.6053 \\
\hline & $\mathrm{y}$ & 12.0580 & 3.8534 & 11.4255 & 3.8889 & 32.4925 & 9.8047 & 31.9007 & 9.6670 \\
\hline \multirow[t]{2}{*}{ PMD } & $\mathrm{x}$ & 527.8607 & 739.7959 & 492.2057 & 776.6423 & 558.3135 & 731.0902 & 538.2028 & 754.4402 \\
\hline & $\mathrm{y}$ & 112.8206 & 36.0546 & 106.9022 & 36.3867 & 121.2635 & 36.5917 & 119.0550 & 36.0777 \\
\hline \multirow[t]{2}{*}{ PAD } & $\mathrm{x}$ & 670.6391 & 901.8662 & 614.7813 & 970.1781 & 664.1276 & 830.5449 & 637.3268 & 869.1879 \\
\hline & $\mathrm{y}$ & 140.0512 & 44.7568 & 132.7043 & 45.1690 & 139.6486 & 42.1395 & 137.1053 & 41.5475 \\
\hline
\end{tabular}




\begin{tabular}{|c|c|c|c|c|c|c|c|c|c|}
\hline \multicolumn{10}{|c|}{ Date $3(02 / 07 / 2017)$} \\
\hline $\mathrm{R}^{2} \mathrm{aj}$ & & 0.8721 & 0.8967 & 0.9532 & 0.8850 & 0.8758 & 0.9086 & 0.9598 & 0.8935 \\
\hline AIC & & 5.5022 & 2.7346 & 4.5516 & 2.7663 & 5.4733 & 2.6138 & 4.4004 & 2.6913 \\
\hline RSD & & 15.3054 & 3.8503 & 9.4845 & 3.9011 & 15.0846 & 3.6234 & 8.7865 & 3.7549 \\
\hline PE & & 1.7585 & 2.8176 & 0.5242 & 1.2864 & 0.8139 & 0.8563 & 0.2747 & 0.5979 \\
\hline IN & & 0.1109 & 0.1576 & 0.0782 & 0.1527 & 0.0990 & 0.1119 & 0.0622 & 0.1126 \\
\hline \multirow[t]{2}{*}{ PI } & $\mathrm{x}$ & 503.4340 & 641.7491 & 423.0108 & 523.0511 & 554.4819 & 662.8515 & 469.5409 & 570.2227 \\
\hline & $\mathrm{y}$ & 53.4595 & 15.7632 & 52.3595 & 12.6983 & 64.5501 & 17.1092 & 66.7180 & 15.7008 \\
\hline \multirow[t]{2}{*}{ PMA } & $\mathrm{x}$ & 300.0530 & 441.7177 & 284.5440 & 363.7896 & 398.2114 & 535.9451 & 354.5747 & 446.7821 \\
\hline & $\mathrm{y}$ & 10.6004 & 3.1257 & 10.3823 & 2.5179 & 27.2821 & 7.2312 & 28.1983 & 6.6360 \\
\hline \multirow[t]{2}{*}{ PMD } & $\mathrm{x}$ & 706.8150 & 841.7805 & 561.4776 & 682.3126 & 710.7524 & 789.7579 & 584.5071 & 693.6632 \\
\hline & $\mathrm{y}$ & 99.1821 & 29.2451 & 97.1414 & 23.5588 & 101.8182 & 26.9872 & 105.2376 & 24.7657 \\
\hline \multirow[t]{2}{*}{ PAD } & $\mathrm{x}$ & 883.2285 & 1015.2885 & 681.5842 & 820.4566 & 826.5023 & 883.7577 & 669.6628 & $785.095 \mathrm{C}$ \\
\hline & $\mathrm{y}$ & 123.1210 & 36.3038 & 120.5877 & 29.2450 & 117.2551 & 31.0789 & 121.1930 & 28.5205 \\
\hline \multicolumn{10}{|c|}{ Date $4(02 / 24 / 2017)$} \\
\hline $\mathrm{R}^{2} \mathrm{aj}$ & & 0.9513 & 0.9580 & 0.9227 & 0.9253 & 0.9589 & 0.9654 & 0.9253 & 0.9362 \\
\hline AIC & & 4.8499 & 1.4899 & 4.9604 & 1.8443 & 4.6828 & 1.3039 & 4.9264 & 1.6883 \\
\hline RSD & & 11.0127 & 2.0619 & 11.5937 & 2.4556 & 10.1133 & 1.8722 & 11.3978 & 2.2691 \\
\hline PE & & 1.4031 & 2.5545 & 1.6202 & 1.3287 & 0.5222 & 0.7083 & 0.7364 & 0.5449 \\
\hline IN & & 0.1286 & 0.1389 & 0.1193 & 0.1484 & 0.0831 & 0.0884 & 0.0915 & 0.1001 \\
\hline \multirow[t]{2}{*}{ PI } & $\mathrm{x}$ & 423.9332 & 495.9976 & 379.0141 & 430.2752 & 451.2401 & 504.6552 & 414.1579 & 463.9403 \\
\hline & $\mathrm{y}$ & 61.2853 & 14.1952 & 52.3293 & 10.6343 & 71.8664 & 15.0133 & 62.9607 & 12.7960 \\
\hline \multirow[t]{2}{*}{ PMA } & $\mathrm{x}$ & 296.3861 & 365.2122 & 240.3725 & 300.8098 & 360.2878 & 421.7518 & 308.6077 & 369.1084 \\
\hline & $\mathrm{y}$ & 12.1521 & 2.8147 & 10.3763 & 2.1086 & 30.3744 & 6.3454 & 26.6103 & 5.4082 \\
\hline \multirow[t]{2}{*}{ PMD } & $\mathrm{x}$ & 551.4804 & 626.7830 & 517.6556 & 559.7407 & 542.1924 & 587.5586 & 519.7081 & 558.7721 \\
\hline & $\mathrm{y}$ & 113.7012 & 26.3360 & 97.0854 & 19.7295 & 113.3587 & 23.6812 & 99.3111 & 20.1837 \\
\hline \multirow[t]{2}{*}{ PAD } & $\mathrm{x}$ & 662.1153 & 740.2267 & 637.9138 & 672.0396 & 609.5610 & 648.9654 & 597.8893 & 629.0142 \\
\hline & $\mathrm{y}$ & 141.1444 & 32.6925 & 120.5181 & 24.4914 & 130.5453 & 27.2716 & 114.3679 & 23.2438 \\
\hline
\end{tabular}

Note. ${ }^{(1)} \mathrm{R}^{2}$ aj: adjusted coefficient of determination; AIC: Akaike information criterion; RSD: residual standard deviation; IN: intrinsic nonlinearity; PE: parameter-effects nonlinearity; PI: point of inflection; PMA: point of maximum acceleration; PMD: point of maximum deceleration; PAD: point of asymptotic deceleration.

Comparing the models, based on the fit quality indicators, we found that overall, the Logistic model presented the highest $\mathrm{R}^{2}$ aj and the lowest AIC and RSD values, indicating its suitability to describe the sudangrass growth. It also had the lowest of PE and IN values, showing that it is closer to linear, confirming its better quality. Prado et al. (2013) and Muniz et al. (2017) had similar conclusions, reporting a better performance of the Logistic model to describe the growth of dwarf coconut and cacao, respectively.

We can use the critical points of the growth curves to infer on crop growth. The main point to consider is the inflection point, which represents the time when the plant reaches the middle of the cycle, the highest growth rate, and from which the growth rate begins to slow. Comparing the models fitted as a function of ATS (Table 3) and ASR (Table 4), we see that in the Logistic model the plants reached PI with higher fresh and dry shoot masses, but they needed greater accumulation of thermal sum and/or solar radiation than in the Gompertz model.

Table 4. Fit quality indicators and critical points of the Gompertz and Logistic models for the traits of fresh shoot mass (FSM) and dry shoot mass (DSM) as a function of accumulated solar radiation $\left(\mathrm{MJm}^{-2}\right)$ for sudangrass cultivars BRS Estribo and CG Farrapo in four sowing times

\begin{tabular}{|c|c|c|c|c|c|c|c|c|}
\hline \multirow{3}{*}{ Statistic } & \multicolumn{4}{|c|}{ 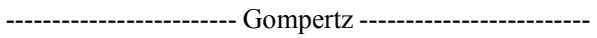 } & \multicolumn{4}{|c|}{ 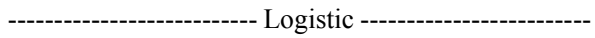 } \\
\hline & \multicolumn{2}{|c|}{ BRS Estribo } & \multicolumn{2}{|c|}{ CG Farrapo } & \multicolumn{2}{|c|}{ BRS Estribo } & \multicolumn{2}{|c|}{ CG Farrapo } \\
\hline & FSM & DSM & FSM & DSM & FSM & DSM & FSM & DSM \\
\hline \multicolumn{9}{|c|}{ Date $1(12 / 20 / 2016)$} \\
\hline $\mathrm{R}^{2} \mathrm{aj}$ & 0.8994 & 0.8919 & 0.9614 & 0.9152 & 0.8981 & 0.8972 & 0.9634 & 0.9111 \\
\hline AIC & 5.5464 & 2.7101 & 4.5026 & 2.5366 & 5.5590 & 2.6611 & 4.4490 & 2.5830 \\
\hline RSD & 15.4595 & 3.7651 & 9.2134 & 3.4601 & 15.5598 & 3.6723 & 8.9643 & 3.5429 \\
\hline PE & 1.4748 & 2.2078 & 0.3832 & 0.7799 & 0.7591 & 0.8879 & 0.2385 & 0.4676 \\
\hline
\end{tabular}




\begin{tabular}{|c|c|c|c|c|c|c|c|c|c|}
\hline IN & & 0.1281 & 0.1783 & 0.0908 & 0.1514 & 0.1168 & 0.1250 & 0.0718 & 0.1139 \\
\hline \multirow[t]{2}{*}{ PI } & $\mathrm{x}$ & 567.7546 & 721.9606 & 510.4711 & 628.3964 & 630.5885 & 776.1997 & 576.2484 & 700.8406 \\
\hline & $\mathrm{y}$ & 57.9437 & 14.3277 & 51.4882 & 12.7371 & 71.1547 & 16.6561 & 67.1446 & 16.1842 \\
\hline \multirow[t]{2}{*}{ PMA } & $\mathrm{x}$ & 340.9463 & 447.2333 & 341.8081 & 409.2162 & 451.1584 & 580.0265 & 429.4762 & 516.6013 \\
\hline & $\mathrm{y}$ & 11.4895 & 2.8410 & 10.2095 & 2.5256 & 30.0735 & 7.0397 & 28.3786 & 6.8403 \\
\hline \multirow[t]{2}{*}{ PMD } & $\mathrm{x}$ & 794.5629 & 996.6880 & 679.1342 & 847.5765 & 810.0186 & 972.3728 & 723.0206 & 885.0799 \\
\hline & $\mathrm{y}$ & 107.5015 & 26.5818 & 95.5249 & 23.6309 & 112.2357 & 26.2726 & 105.9105 & 25.5282 \\
\hline \multirow[t]{2}{*}{ PAD } & $\mathrm{x}$ & 991.2974 & 1234.9875 & 825.4332 & 1037.6943 & 942.9228 & 1117.6788 & 831.7350 & 1021.5464 \\
\hline & $\mathrm{y}$ & 133.4483 & 32.9976 & 118.5810 & 29.3345 & 129.2521 & 30.2559 & 121.9679 & 29.3986 \\
\hline \multicolumn{10}{|c|}{ Date $2(01 / 20 / 2017)$} \\
\hline $\mathrm{R}^{2} \mathrm{aj}$ & & 0.8816 & 0.8910 & 0.9464 & 0.9292 & 0.8765 & 0.8976 & 0.9340 & 0.9376 \\
\hline AIC & & 5.5859 & 3.3985 & 4.7508 & 2.7961 & 5.6272 & 3.3371 & 4.4420 & 2.6695 \\
\hline RSD & & 15.7976 & 5.3386 & 10.4429 & 3.9496 & 16.1298 & 5.1750 & 11.5820 & 3.7066 \\
\hline $\mathrm{PE}$ & & 0.7562 & 1.5868 & 0.3196 & 0.9959 & 0.4943 & 0.6500 & 0.2626 & 0.4303 \\
\hline IN & & 0.0880 & 0.1377 & 0.0575 & 0.0891 & 0.1025 & 0.1026 & 0.0732 & 0.0742 \\
\hline \multirow[t]{2}{*}{ PI } & $\mathrm{x}$ & 449.8334 & 703.4069 & 439.9603 & 669.8794 & 511.9898 & 762.9632 & 502.5705 & 739.4541 \\
\hline & $\mathrm{y}$ & 57.2636 & 19.5408 & 56.1860 & 18.3019 & 74.0135 & 23.2197 & 74.3676 & 22.2185 \\
\hline \multirow[t]{2}{*}{ PMA } & $\mathrm{x}$ & 274.0614 & 436.6189 & 283.3963 & 402.6465 & 354.7527 & 568.4901 & 351.7371 & 539.5142 \\
\hline & $\mathrm{y}$ & 11.3547 & 3.8747 & 11.1410 & 3.6291 & 31.2818 & 9.8138 & 31.4315 & 9.3906 \\
\hline \multirow[t]{2}{*}{ PMD } & $\mathrm{x}$ & 625.6055 & 970.1949 & 596.5244 & 937.1123 & 669.2269 & 957.4364 & 653.4038 & 939.3941 \\
\hline & $\mathrm{y}$ & 106.2399 & 36.2535 & 104.2406 & 33.9552 & 116.7452 & 36.6256 & 117.3038 & 35.0463 \\
\hline \multirow[t]{2}{*}{ PAD } & $\mathrm{x}$ & 778.0708 & 1201.6078 & 732.3286 & 1168.9112 & 785.6928 & 1101.4831 & 765.1264 & 1087.4901 \\
\hline & $\mathrm{y}$ & 131.8822 & 45.0037 & 129.4003 & 42.1506 & 134.4452 & 42.1786 & 135.0886 & 40.3598 \\
\hline \multicolumn{10}{|c|}{ Date $3(02 / 07 / 2017)$} \\
\hline $\mathrm{R}^{2} \mathrm{aj}$ & & 0.8646 & 0.8801 & 0.9548 & 0.8747 & 0.8691 & 0.8975 & 0.9581 & 0.8852 \\
\hline AIC & & 5.5591 & 2.8726 & 4.5177 & 2.8521 & 5.5257 & 2.7189 & 4.4420 & 2.7657 \\
\hline RSD & & 15.7465 & 4.1488 & 9.3170 & 4.0716 & 15.4851 & 3.8365 & 8.9700 & 3.8981 \\
\hline $\mathrm{PE}$ & & 2.6416 & 2.3572 & 0.7096 & 1.9144 & 1.1021 & 0.8023 & 0.3640 & 0.7930 \\
\hline IN & & 0.0935 & 0.2006 & 0.0555 & 0.1596 & 0.0984 & 0.1335 & 0.0579 & 0.1185 \\
\hline \multirow[t]{2}{*}{ PI } & $\mathrm{x}$ & 646.9873 & 799.4523 & 508.5073 & 666.7369 & 709.4531 & 842.9775 & 577.0935 & 726.3944 \\
\hline & $\mathrm{y}$ & 57.7763 & 14.8261 & 54.2502 & 13.5421 & 66.9240 & 16.9650 & 67.8805 & 16.0682 \\
\hline \multirow[t]{2}{*}{ PMA } & $\mathrm{x}$ & 325.1009 & 563.9750 & 287.1111 & 415.8039 & 476.3871 & 684.0584 & 397.3661 & 545.8556 \\
\hline & $\mathrm{y}$ & 11.4564 & 2.9398 & 10.7572 & 2.6852 & 28.2856 & 7.1703 & 28.6897 & 6.7912 \\
\hline \multirow[t]{2}{*}{ PMD } & $\mathrm{x}$ & 968.8737 & 1034.9296 & 729.9036 & 917.6699 & 942.5192 & 1001.8966 & 756.8209 & 906.9333 \\
\hline & $\mathrm{y}$ & 107.1911 & 27.5066 & 100.6491 & 25.1243 & 105.5632 & 26.7598 & 107.0716 & 25.3451 \\
\hline \multirow[t]{2}{*}{ PAD } & $\mathrm{x}$ & 1248.0792 & 1239.1835 & 921.9435 & 1135.3301 & 1115.1517 & 1119.6084 & 889.9455 & 1040.6588 \\
\hline & $\mathrm{y}$ & 133.0630 & 34.1457 & 124.9420 & 31.1884 & 121.5679 & 30.8170 & 123.3050 & 29.1877 \\
\hline \multicolumn{10}{|c|}{ Date $4(02 / 24 / 2017)$} \\
\hline $\mathrm{R}^{2} \mathrm{aj}$ & & 0.9459 & 0.9587 & 0.9152 & 0.9276 & 0.9581 & 0.9669 & 0.9251 & 0.9407 \\
\hline $\mathrm{AIC}$ & & 4.9406 & 1.4576 & 5.0510 & 1.8044 & 4.6960 & 1.2555 & 4.9285 & 1.6117 \\
\hline RSD & & 11.6086 & 2.0459 & 12.1445 & 2.4183 & 10.2133 & 1.8321 & 11.4131 & 2.1876 \\
\hline PE & & 0.7080 & 0.7356 & 1.0204 & 0.7341 & 0.3379 & 0.3308 & 0.5016 & 0.3560 \\
\hline $\mathrm{IN}$ & & 0.1369 & 0.1111 & 0.1561 & 0.1502 & 0.0916 & 0.0786 & 0.1048 & 0.1002 \\
\hline \multirow[t]{2}{*}{ PI } & $\mathrm{x}$ & 583.8386 & 647.5544 & 530.0817 & 595.7359 & 624.4562 & 681.6803 & 579.7270 & 640.7866 \\
\hline & $\mathrm{y}$ & 54.3577 & 11.0590 & 48.7877 & 9.6733 & 69.0014 & 13.8855 & 61.0595 & 12.3547 \\
\hline \multirow[t]{2}{*}{ PMA } & $\mathrm{x}$ & 462.3869 & 536.4276 & 378.2640 & 465.8083 & 525.0526 & 591.0428 & 459.5737 & 533.7015 \\
\hline & $\mathrm{y}$ & 10.7785 & 2.1929 & 9.6740 & 1.9181 & 29.1634 & 5.8687 & 25.8067 & 5.2217 \\
\hline \multirow[t]{2}{*}{ PMD } & $\mathrm{x}$ & 705.2903 & 758.6813 & 681.8995 & 725.6634 & 723.8599 & 772.3178 & 699.8803 & 747.8718 \\
\hline & $\mathrm{y}$ & 100.8485 & 20.5175 & 90.5146 & 17.9467 & 108.8395 & 21.9023 & 96.3120 & 19.4877 \\
\hline \multirow[t]{2}{*}{ PAD } & $\mathrm{x}$ & 810.6380 & 855.0732 & 813.5868 & 838.3631 & 797.4884 & 839.4532 & 788.8781 & 827.1899 \\
\hline & $\mathrm{y}$ & 125.1895 & 25.4697 & 112.3614 & 22.2783 & 125.3409 & 25.2229 & 110.9142 & 22.4423 \\
\hline
\end{tabular}

Note. ${ }^{(1)} \mathrm{R}^{2}$ aj: adjusted coefficient of determination; AIC: Akaike information criterion; RSD: residual standard deviation; IN: intrinsic nonlinearity; PE: parameter-effects nonlinearity; PI: point of inflection; PMA: point of maximum acceleration; PMD: point of maximum deceleration; PAD: point of asymptotic deceleration. 
Figures 2 and 3 show the growth curves with their respective critical points for the Logistic model, which is the most indicated. It can be seen that cv. CG Farrapo required less accumulation of thermal sum and/or solar radiation to reach the PI compared with cv. BRS Estribo, but presented lower FSM and DSM. Differences between the thermal sum requirements to reach the inflection point were also observed by Deprá, Lopes, Noal, Reininger and Cocco (2016) in maize cultivars.
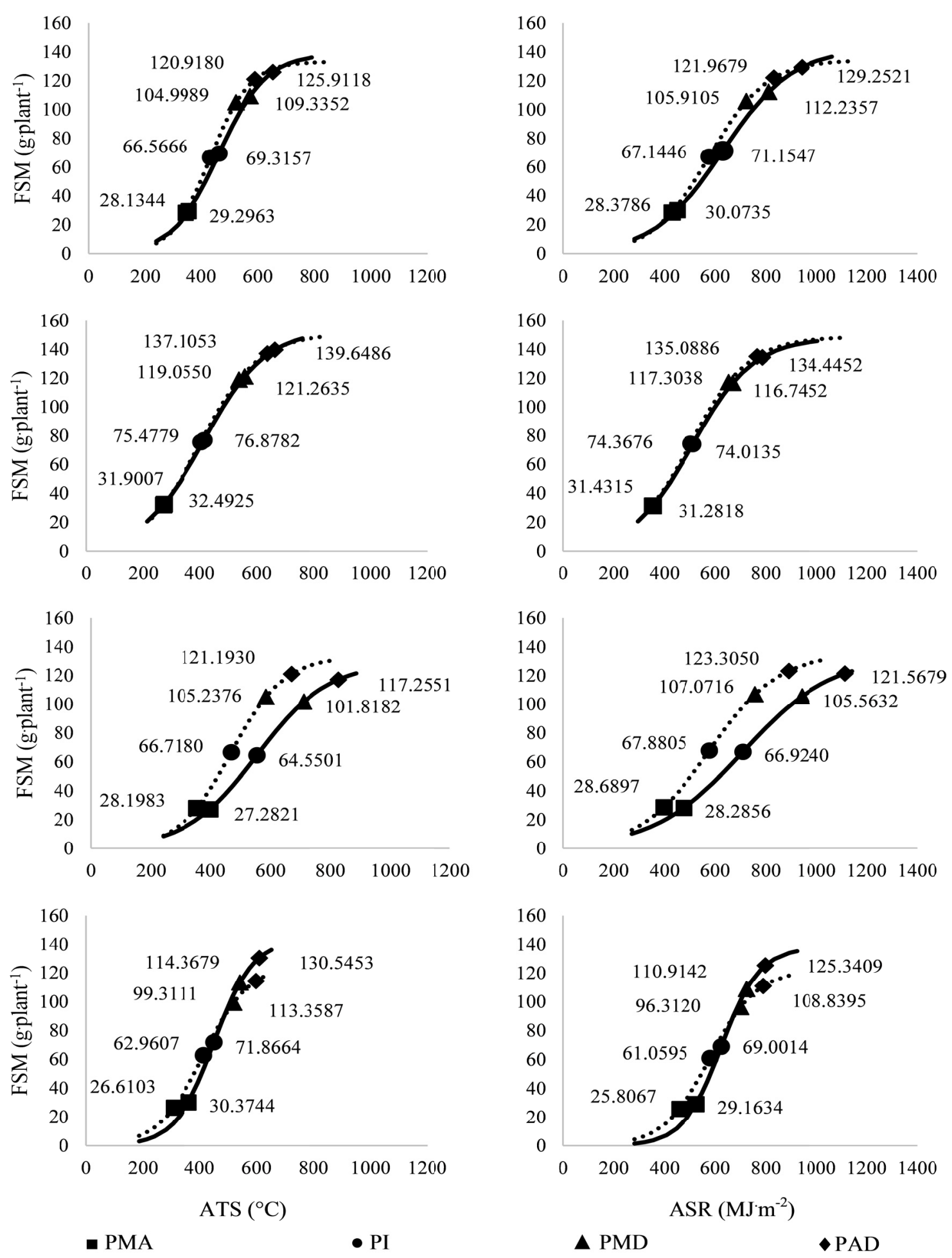

Figure 2. Graphs of the Logistic models for the fresh shoot mass (FSM, g plant ${ }^{-1}$ ) as a function of accumulated thermal sum $\left(\mathrm{STA}\right.$, in ${ }^{\circ} \mathrm{C}$ ) and accumulated solar radiation (ASR, in $\mathrm{MJ} \mathrm{m}^{-2}$ ), of sudangrass cultivars BRS Estribo ( $(-)$ and CG Farrapo (......) in four sowing times 

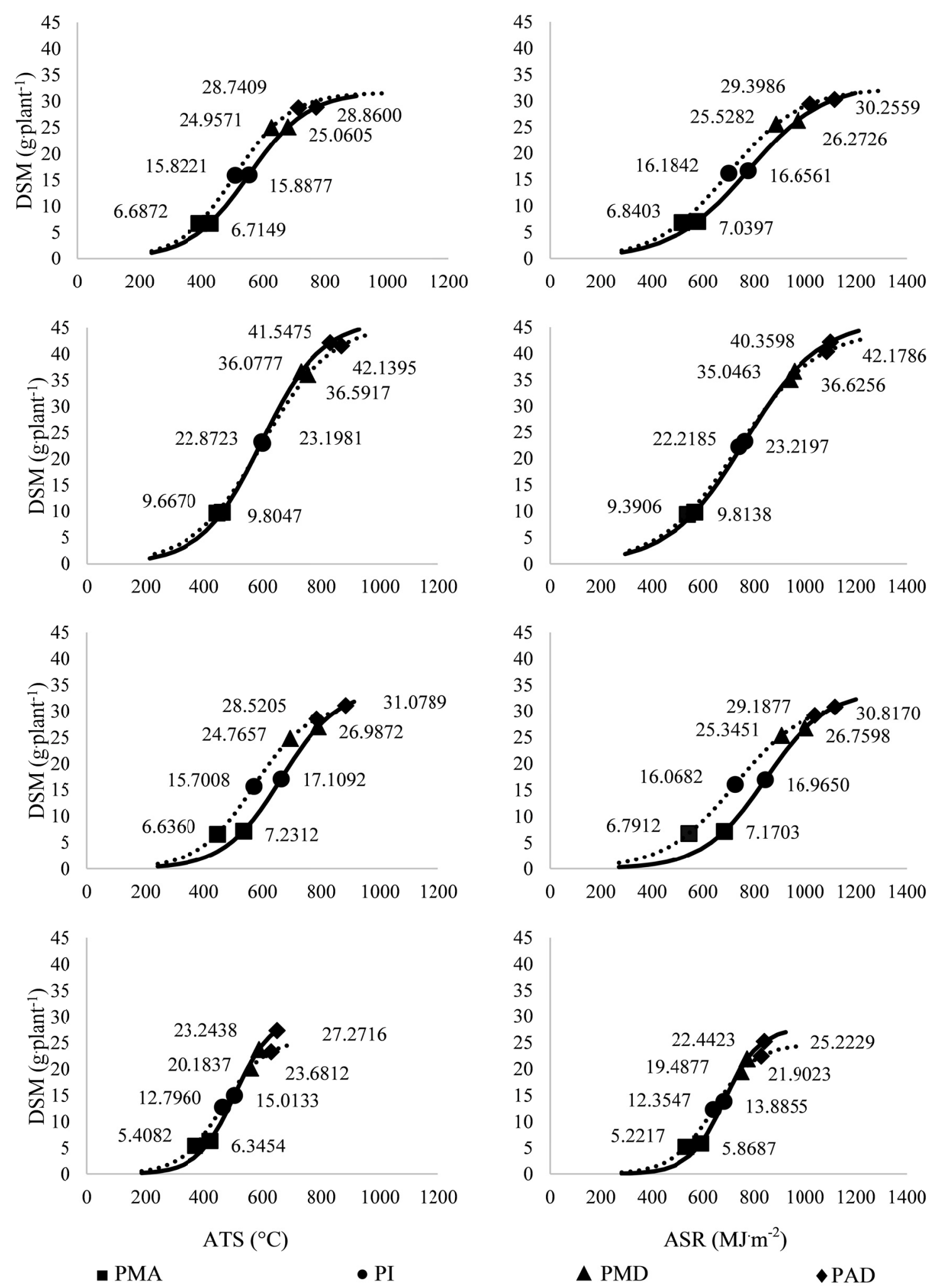

Figure 3. Graphs of the Logistic models for the dry shoot mass (DSM, $g$ plant ${ }^{-1}$ ) as a function of accumulated thermal sum (STA, in ${ }^{\circ} \mathrm{C}$ ) and accumulated solar radiation (ASR, in $\mathrm{MJ}^{-2}$ ), of sundangrass cultivars BRS Estribo (-) and CG Farrapo (…..) in four sowing times

In general, for the other points, cv. CG Farrapo reaches PMA, PMD, and PAD with lower of ATS and/or ASR values compared with cv. BRS Estribo. Therefore, we can infer that cv. CG Farrapo has a shorter cycle, with 
growth rate acceleration and deceleration taking place earlier than in cv. CG Farrapo. Hence, we recommend that the cultural practices, such as topdressing, weed and pest control, should be carried out earlier in cv. CG Farrapo than in cv. BRS Estribo.

Analyzing the sowing dates, we observe that the second date (20/01) presented the highest FSM and DSM values at all the critical points, which can indicate the best sowing date for the crop, aiming at greater yield of fresh and dry shoot masses.

Overall, differences were found between the cultivars within the sowing dates and between the sowing dates within each cultivar. In this way, the researcher carrying out studies with Sudan grass should choose the model that best describes the growth of a particular cultivar at a given time of interest.

Because the information of the present study was generated from the data obtained for cultivars BRS Estribo and CG Farrapo grown in the environmental conditions in which they were studied, the use of these models could produce results with some discrepancies, however this is expected. Nevertheless, due to the representativeness of the database used to fit the models in this study (three weekly evaluations of five plants during the crop cycle, in two cultivars sown in four dates) and the fact that no studies were found with growth models for Sudangrass, these models can be used as reference for further investigations in the crop.

\section{Conclusions}

The independent variables accumulated thermal sum and accumulated solar radiation can be used satisfactorily to fit the Gompertz and Logistic models to fit cultivars of sudangrass.

There is difference between the growth models of the cultivars within sowing dates and between the sowing dates within a cultivar for the traits fresh shoot mass and dry shoot mass.

The Gompertz and Logistic models satisfactorily describe the growth of fresh shoot mass and dry shoot mass of the sudangrass cultivars BRS Estribo and CG Farrapo sown at four dates. The Logistic model is more indicated as it presents better fit quality indicators.

\section{Acknowledgements}

We thank the Brazilian National Council for Scientific and Technological Development (CNPq-Processes 401045/2016-1 and 304652/2017-2), the Coordination for the Improvement of Higher Education Personnel (CAPES), and the Rio Grande do Sul Research Foundation (FAPERGS) for granting scholarships.

\section{References}

Alvares, C. A., Stape, J. L., Sentelhas, P. C., Gonçalves, J. L. M., \& Sparovek, G. (2013). Köppen's climate classification map for Brazil. Meteorologische Zeitschrift, 22(6), 711-728. https://doi.org/10.1127/ 0941-2948/2013/0507

Arenhardt, E. G., Silva, J. A. G., Gewehr, E., Arenhardt, L. G., Arenhardt, C. L., \& Nonnenmacher, G. (2016). CG Farrapo: A sudangrass cultivar with high biomass and grain yields. Crop Breeding and Applied Biotechnology, 16(2), 158-162. https://doi.org/10.1590/1984-70332016v16n2c24

Arnold, C. Y. (1960). Maximum-Minimum temperature as a basis for computing heat units. Proceedings of the American Society for Horticultural Science, 76, 682-692.

Bandeira, A. H., Medeiros, S. L. P., Emygdio, B. M., Biondo, J. C., Silva, N. G., \& Leal, L. T. (2016). Low base temperature (tb) and thermal demand of sweet sorghum genotypes. Revista Brasileira de Milho e Sorgo, 15(2), 240-250. https://doi.org/10.18512/1980-6477/rbms.v15n2p240-250

Batista, E. L. S., Zolnier, S., Ribeiro, A., Lyra, G. B., Silva, T. G. F., \& Boehringer, D. (2013). Modeling of growth of sugarcane cultivars during the crop formation period. Revista Brasileira de Engenharia Agrícola e Ambiental, 17(10), 1080-1087. https://doi.org/10.1590/S1415-43662013001000009

Bem, C. M., Cargnelutti Filho, A., Chaves, G. G., Kleinpaul, J. A., Pezzini, R. V., \& Lavezo, A. (2018). Gompertz and Logistic Models to the Productive Traits of Sunn Hemp. Journal of Agricultural Science, 10(1), 225-238. https://doi.org/10.5539/jas.v10n1p225

Borges, W. L. B., Freitas, R. S., Mateus, G. P., Sá, M. E., \& Alves, M. C. (2014). Weed suppression by cover crops soil. Planta Daninha, 32(4), 755-763. https://doi.org/10.1590/S0100-83582014000400010

Cardoso, D. P., Silva, M. L. N., Carvalho, G. J., Freitas, D. A. F., \& Avanzi, J. C. (2012). Cover crops to control soil, water and nutrient losses by water erosion. Revista Brasileira de Engenharia Agrícola e Ambiental, 16(6), 632-638. https://doi.org/10.1590/S1415-43662012000600007 
Deprá, M. S., Lopes, S. J., Noal, G., Reininger, L. R. S., \& Cocco, D. T. (2016). Logistic growing model of corn creole cultivate and maternal progenies of half-brothers as a function of thermal time. Ciência Rural, 46(1), 36-43. https://doi.org/10.1590/0103-8478cr20140897

Fernandes, T. J., Pereira, A. A., Muniz, J. A., \& Savian, T. V. (2014). Selection of nonlinear models for the description of the growth curves of coffee fruit. Coffee Science, 9(2), 207-215.

Lucena, L. R. R., Leite, M. L. M. V., Pereira, J. S., \& Cavalcante, A. B. (2016). Ajuste de curvas de crescimento do comprimento do cladódio de Nopalea Cochenillifera. Biomatemática, 26, 39-52.

Mattos, J. L. S. (2003). Alternative grasses forage annuals for Brazil central region. Revista do Programa de Ciências Agro-Ambientais, 2(1), 52-70.

Mischan, M. M., \& Pinho, S. Z. (2014). Modelos não lineares: Funções assintóticas de crescimento. São Paulo: Cultura Acadêmica.

Muniz, J. A., Nascimento, M. S., \& Fernandes, T. J. (2017). Nonlinear models for description of cacao fruit growth with assumption violations. Revista Caatinga, 30(1), 250-257. https://doi.org/10.1590/ 1983-21252017v30n128rc

Oliveira, A. S., Ribeiro, A., Silva, C. R. A., Xavier, A., \& Freitas, A. F. (2017). Modeling the growth of eucalyptus plants based on the thermal sum. Revista Árvore, 41(2), 1-10. https://doi.org/10.1590/ 1806-90882017000200012

Pacheco, L. P., Barbosa, J. M., Leandro, W. M., Machado, P. L. O. A., Assis, R. L., Madari, B. E., \& Petter, F. A. (2013). Nutrient cycling by cover crops and yield of soybean and rice in no-tillage. Pesquisa Agropecuária Brasileira, 48(9), 1228-1236. https://doi.org/10.1590/S0100-204X2013000900006

Pereira, A. A., Morais, A. R., Scalco, M. S., \& Fernandes, T. J. (2014). Description vegetative growth of coffee tree farming Ruby MG 1192 using regression models. Coffee Science, 9(2), 266-274.

Prado, T. K. L., Savian, T. V., \& Muniz, J. A. (2013). The fit Gompertz and Logístic models to the growth data of green dwarf coconut fruits. Ciência Rural, 43(5), 803-809. https://doi.org/10.1590/ S0103-84782013005000044

$\mathrm{R}$ development Core Team (2018). R: A language and environment for statistical computing. $R$ Foundation for Statistical Computing. Vienna, Austria, Retrieved from http://www.R-project.org/

Ribeiro, T. D., Mattos, R. W. P., Morais, A. R., \& Muniz, J. A. (2018). Description of the growth of pequi fruits by nonlinear models. Revista Brasileira de Fruticultura, 40(4), 1-11. https://doi.org/10.1590/ 0100-29452018949

Santos, H. G., Jacomine, P. K. T., Anjos, L. H. C., Oliveira, V. A., Lumbreras, J. F., Coelho, M. R., ... Oliveira, J. B. (2013). Brazilian Soil Classification System (3rd ed.). Brasília, Embrapa.

Silveira, M. C. T., Santanna, D. M., Montardo, D. P., \& Trentin, G. (2015). Aspectos relativos à implantação e manejo de Capim-Sudão BRS Estribo. Bagé, Embrapa Pecuária Sul.

\section{Copyrights}

Copyright for this article is retained by the author(s), with first publication rights granted to the journal.

This is an open-access article distributed under the terms and conditions of the Creative Commons Attribution license (http://creativecommons.org/licenses/by/4.0/). 